\title{
Biochemical Changes During Withering Process of CTC black Tea Manufacture
}

\section{SITHARANJAN KALIDASS ${ }^{1 *}$, KARUPPANA UDAIYAR VIJAYA² and RAJAGOPAL RAJ KUMAR ${ }^{3}$}

${ }^{1}$ Research and Development Centre, Bharathiar University, Coimbatore 641 046, Tamil Nadu, India.

2PSNA College of Engineering and Technology, Dindigul, Tamil Nadu, India.

${ }^{3}$ The United Planters Association of Southern India, Tea Research Foundation, Tea Research Institute,

Valparai 642 127, Coimbatore District, Tamil Nadu, India.

*Corresponding author E-mail: skalidassupasi@ rediffmail.com

http://dx.doi.org/10.13005/ojc/350409

(Received: May 18, 2019; Accepted: July 14, 2019)

\begin{abstract}
Tea is one of the unique non-alcoholic beverages consumed all over the world next to water. During manufacturing process of CTC made tea, withering is one of the important stage where in physical changes taken place besides certain biochemical variations. Current research was carried out the biochemical changes in the green leaves and quality attributes of made tea with respect to extended withering period using "Assam" seedlings and an unique "Chinery" clone, UPASI-9. Results on biochemical constituents of the both withered green leaves and made teas of "Assam" seedlings and UPASI-9 followed identical pattern with certain deviations. Polyphenols transformed rapidly in "Assam" seedlings while it was found to slow in UPASI-9. Processed teas showed irregular pattern in terms of TF, TR, TLC and WE values in both the test materials. TR:TF ratio enhanced in UPASI-9, after $12 \mathrm{~h}$ of withering period. Overall results revealed that withering of harvested green leaves till $16 \mathrm{~h}$ could be the optimum time to achieve the quality teas with desired flavor. Data generated on withered green leaf constituents and made tea attributes of both the test materials are presented and discussed in detail.
\end{abstract}

Keywords: Tea, Extended withering, Biochemical parameters, Quality attributes.

\section{INTRODUCTION}

Tea (Camellia sps.), a non-alcoholic beverage is consumed world-wide from dawn to dusk, next to water, the "Adam's" wine. Classically, tea plants were classified in to two major taxa, i.e., small leaved "China" jat and broad and large leaved "Assam" type. Later, taxonomists positioned the tea plants into three distinct taxa as "Assam", "China" and Cambod" jats (Barua, 1989). Quality of manufactured tea has composite characters depending on polyphenols, catechins, proteins, caffeine, carbohydrates, enzymes and certain intermediary constituents present in the tender

This is an Open Access article licensed under a Creative Commons license: Attribution 4.0 International (CC- BY). Published by Oriental Scientific Publishing Company @ 2018

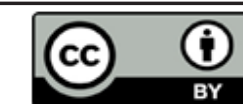


crop shoots ${ }^{2,3}$. Withering is pre-requisite, first step in black tea processing wherein consistency in oxidation during fermentation was ensured ${ }^{4}$. Earlier, Dev Choudhury and Bajaj ${ }^{5}$ reviewed the chemistry of withering and later Ullah ${ }^{6}$ established the importance of physical withering during black tea manufacture. Both physical and chemical withering gained importance in black tea manufactures in order to achieve the final produce with good aroma and flavor ${ }^{7,8}$. Scanty information was reported on extended withering period with particular reference to specific jat/clone on final produce. In this context, to study the biochemical changes during extended withering period with two distinct varieties and their quality attributes of final produce was envisaged in the present endeavor.

\section{MATERIALS AND METHODS}

The present study was carried out at the UPASI Tea Research Foundation, Tea Research Institute, elevated at $1150 \mathrm{~m}$ above MSL situated at Valparai 642 127, Tamil Nadu, India. The crop shoots were collected from UPASI Tea Research Experimental Farm; UPASI released clonal tea plant, UPASI-9 and "Assam" seedlings are the test materials. Crop shoots (two to three leaves and terminal bud) collected individually were subjected to the analysis of green leaf constituents and preparation of made tea. During withering process, samples were drawn at $2.0 \mathrm{~h}$ intervals till extended withering period $(20 \mathrm{~h})$ and subjected to determination of green leaf constituents. All the experiments were conducted between 2015 and 2016.

\section{Determination of green leaf constituents}

Crop shoots with uniform physiological maturity were collected from the field grown tea bushes for quantification of green leaf attributes like polyphenols, catechins, amino acids, etc., following the standard protocols. Amount of polyphenols present in the tea leaves (fresh/withered leaves) were quantified in accordance with Dev Choudhury and Goswami ${ }^{9}$ while catechin content was determined as per Swain and Hillis ${ }^{10}$. As per the protocol suggested by Moore and Stein ${ }^{11}$ the total free amino acids were quantified and the pigments (both chlorophylls and carotenoids) were estimated by colorimetric method reported by Wellburn ${ }^{12}$. Concentration of reducing sugars was determined using the protocol reported by Hedge and Hofreiter ${ }^{13}$. Quantification of lipids was determined gravimetrically in accordance with Ravichandran and Parthiban ${ }^{14}$ while caffeine was estimated the method suggested by Ronald and Ronald ${ }^{15}$.

\section{CTC black tea manufacture}

About $3.0 \mathrm{~kg}$ of two to three leaves and a bud were collected individually from field grown "Assam" seedlings and the clone, UPASI-9 and brought to the miniature manufacturing unit. Harvested crop was spread out on wire trays and allowed to wither up to $20 \mathrm{~h}$ to achieve a $25-30 \%$ decrease in fresh weight. Withered shoots were passed through a CTC (crush, tear and curl) machine for maceration. After maceration, cut "dhool" was spread out in trays for an optimum fermentation period (45-60 min depending on the type of the tea clone). Fermented "dhool" was dried in a mini fluid bed drier at $107^{\circ} \mathrm{C}$ for 20 minutes. Samples were sorted out, packed individually in polyethylene bags, labelle and stored for analysis of quality constituents ${ }^{16}$. It may be noted that between 2 and $10 \mathrm{~h}$ the moisture content was relatively more, manufactured black tea samples showed erratic results and hence the samples drawn from 10 to $20 \mathrm{~h}$ at an interval of $2 \mathrm{~h}$ were considered in the present study.

\section{Quantification of black tea attributes}

Made tea was assessed for its primary quality constituents such as theaflavins (TF), therubigins (TR), high polymerized substances (HPS) and total liquor colour (TLC) using spectrophotometric method $^{17}$. Caffeine content in ublack tea samples was quantified adopting the procedure reported by Ullah et al., ${ }^{18}$. Colour index and briskness index were computed with the values of TF, TR, HPS and caffeine ${ }^{19}, T R, T F$ ratio was computed with the values of TF and TR of respective samples. Water extract (total soluble solids) of the infusion expressed on dry matter basis was derived in accordance with IS procedure ${ }^{20}$ where as moisture content was determined following the IS method ${ }^{21}$. Crude fibre content was quantified following ISO method ${ }^{22}$.

\section{Statistical analysis}

Data obtained from the triplicate samples and both crop and lean seasons were subjected to statistical analysis, analysis of variance (ANOVA) and the differences that existed among the results were compared with critical difference (C.D.) at five per cent probability. To establish the precision of the 
experimental design and its execution, values of coefficient of variation (C.V.) in per cent were also presented individually for each parameter ${ }^{23}$.

\section{RESULTS}

As withering period increases from 2 to 16 $\mathrm{h}$ the polyphenol content of the harvested green leaf declined significantly from 27.78 to $23.42 \%$ (Table 1). Extended withering period beyond $16 \mathrm{~h}$ exhibited moderate increase in polyphenols. Identical trend was observed in the case of catechins of "Assam" seedling teas. On the other hand, increasing withering period enhanced the amino acid content from $1.24 \%$. Extended withering period showed two fold increase in amino acid content and registered $2.55 \%$. Similar tendency was registered by reducing sugars where it increases from $1.24 \%$ at $2 \mathrm{~h}$ to $2.24 \%$ at 20 hours. Contrarily, both pigments (chlorophylls and carotenoids) reduced significantly from 2.11 to $1.32 \%$ as against the extended withering period, right from 2 to 20 hours. Extended withering of harvested crop shoots declined the lipid content significantly at five per cent probability. As for as caffeine is concerned, caffeine content enhances from 2 to $18 \mathrm{~h}$ and then declined moderately. Overall results on green leaf constituents against withering period revealed that the optimum fermentation period was found to be 16 hours.

Table 1: Green leaf constituents of "Assam" seedlings

\begin{tabular}{ccccccccc}
\hline $\begin{array}{l}\text { Withering } \\
\text { period }(\mathrm{h})\end{array}$ & $\begin{array}{c}\text { Poly- } \\
\text { phenols }\end{array}$ & $\begin{array}{c}\text { Cate- } \\
\text { chins }\end{array}$ & $\begin{array}{c}\text { Amino } \\
\text { acids }\end{array}$ & $\begin{array}{c}\text { Reducing } \\
\text { sugars }\end{array}$ & $\begin{array}{c}\text { Chloro- } \\
\text { phylls } \\
\text { (in per cent) } \\
\text { noids }\end{array}$ & $\begin{array}{c}\text { Carote- } \\
\text { Lipids }\end{array}$ & Caffeine \\
\hline 2 & 27.78 & 14.37 & 1.24 & 1.29 & 2.11 & 0.61 & 8.27 & 2.33 \\
4 & 27.26 & 14.10 & 1.35 & 1.45 & 1.65 & 0.60 & 8.01 & 2.45 \\
6 & 26.18 & 13.95 & 1.45 & 1.52 & 1.60 & 0.58 & 7.74 & 2.55 \\
8 & 26.14 & 13.82 & 1.57 & 1.61 & 1.55 & 0.57 & 7.51 & 2.63 \\
10 & 24.89 & 13.15 & 1.61 & 1.62 & 1.51 & 0.55 & 7.25 & 2.72 \\
12 & 23.89 & 12.61 & 1.75 & 1.67 & 1.44 & 0.52 & 6.95 & 2.78 \\
14 & 23.73 & 12.56 & 1.82 & 1.75 & 1.40 & 0.51 & 6.50 & 2.83 \\
16 & 23.42 & 12.51 & 1.94 & 1.85 & 1.35 & 0.50 & 6.37 & 3.04 \\
18 & 24.45 & 13.08 & 2.23 & 1.93 & 1.35 & 0.49 & 6.20 & 3.18 \\
20 & 24.88 & 13.02 & 2.55 & 2.24 & 1.32 & 0.48 & 5.87 & 2.98 \\
S.E. & 0.92 & 0.71 & 0.46 & 0.34 & 0.21 & 0.04 & 0.78 & 0.41 \\
C.D. & 0.80 & 1.93 & 1.39 & 0.91 & 0.67 & 0.42 & 0.08 & 1.43 \\
C.V. & 7.74 & 5.54 & 3.63 & 2.67 & 1.69 & 0.38 & 5.72 & 3.21 \\
\hline
\end{tabular}

As far as made tea attributes of "Assam" seedlings showed corresponding values (Table 2). Thearubigins increased with increasing time of withering period (from 10 to $18 \mathrm{~h}$ ) significantly at five per cent level and then declined at 20 hours. There was no definite trend in TR and HPS as against extended withering period. However, values of TR:TF ratio dropped from 13.23 to 8.56 as against the extended withering period. The values of TLC increased with increasing withering period. Similar trend was observed in the case of caffeine content as well. Concurrent increase in the $\mathrm{Cl}$ was noticed against the increasing withering period. Contrary to $\mathrm{Cl}, \mathrm{BI}$ values declined from 33.00 to 21.57 which is significant at five per cent level. Water extract showed definite trend against the extended withering wherein WE increased with increasing withering period and then moderately declined. Crude fibre content declined from 14.19 to $12.79 \%$ as against extended withering period.

As withering period increases from 2 to $18 \mathrm{~h}$, the polyphenols declined significantly from 29.32 to $28.18 \%$ (Table 3). Identical trend was observed in the case of catechins of "Chinery" clone. Increasing withering period enhanced the amino acid content from 1.26 to $2.76 \%$ till 20 hours. Identical tendency was registered by reducing sugars where it increases from $1.40 \%$ at $2 \mathrm{~h}$ to $2.75 \%$ at $20 \mathrm{~h}$ as it was observed with "Assam" seedling teas. Both pigments (chlorophylls and carotenoids) reduced significantly as against the extended withering period, right from 2 to 20 hours. Extended withering of harvested crop 
shoots declined the lipid content significantly at five per cent probability, from 7.67 to $5.64 \%$. Caffeine is concerned, caffeine content increases from 2 till $18 \mathrm{~h}$ and then it declined moderately.

Table 2: Made tea quality attributes of "Assam" seedling teas

\begin{tabular}{|c|c|c|c|c|c|c|c|c|c|c|}
\hline $\begin{array}{l}\text { Sampling } \\
\text { time (h) }\end{array}$ & $\begin{array}{l}\text { TF } \\
(\%)\end{array}$ & $\begin{array}{l}\text { TR } \\
(\%)\end{array}$ & $\begin{array}{c}\text { HPS } \\
(\%)\end{array}$ & TLC & $\begin{array}{c}\text { Caffeine } \\
(\%)\end{array}$ & $\mathrm{Cl}$ & $\mathrm{BI}$ & TR:TF & WE (\%) & $\begin{array}{l}\text { CFC } \\
(\%)\end{array}$ \\
\hline 10 & 0.75 & 9.92 & 7.54 & 2.47 & 2.31 & 4.28 & 33.00 & 13.23 & 34.19 & 14.19 \\
\hline 12 & 0.83 & 10.56 & 7.78 & 2.93 & 2.49 & 4.52 & 30.42 & 12.72 & 36.96 & 13.20 \\
\hline 14 & 0.86 & 9.49 & 7.77 & 3.04 & 2.81 & 5.29 & 27.46 & 9.87 & 37.21 & 13.01 \\
\hline 16 & 0.97 & 9.24 & 7.46 & 3.97 & 3.47 & 5.81 & 22.73 & 9.53 & 38.43 & 12.91 \\
\hline 18 & 1.01 & 9.12 & 6.49 & 4.20 & 3.20 & 7.36 & 24.07 & 9.03 & 39.19 & 12.80 \\
\hline 20 & 0.94 & 8.05 & 7.42 & 3.63 & 3.74 & 6.51 & 21.57 & 8.56 & 37.89 & 12.79 \\
\hline S.E. & 0.04 & 0.12 & 0.08 & 0.23 & 0.15 & 0.56 & 1.45 & - & 1.67 & 0.47 \\
\hline C.D. & 0.08 & 0.23 & 0.17 & 0.46 & 0.31 & 1.13 & 2.91 & - & 3.27 & 0.92 \\
\hline C.V. & 7.29 & 6.96 & 4.58 & 9.80 & 10.16 & 8.17 & 6.45 & - & 13.01 & 3.66 \\
\hline \multicolumn{11}{|c|}{ Table 3: Green leaf parameters of Chinery tea clone, UPASI-9 } \\
\hline $\begin{array}{l}\text { Withering } \\
\text { period }(\mathrm{h})\end{array}$ & $\begin{array}{c}\text { Poly- } \\
\text { phenols }\end{array}$ & & $\begin{array}{l}\text { Cate- } \\
\text { chins }\end{array}$ & $\begin{array}{l}\text { Amino } \\
\text { acids }\end{array}$ & $\begin{array}{c}\text { Reducing } \\
\text { sugars }\end{array}$ & \multicolumn{3}{|c|}{$\begin{array}{c}\text { Chloro- } \\
\text { phylls } \\
\text { (in per cent) }\end{array}$} & Lipids & Caffeine \\
\hline 2 & 29.32 & & 14.52 & 1.26 & 1.40 & 1.55 & & 0.73 & 7.67 & 2.53 \\
\hline 4 & 29.31 & & 14.44 & 1.43 & 1.42 & 1.52 & & 0.70 & 7.28 & 2.66 \\
\hline 6 & 29.30 & & 14.38 & 1.53 & 1.46 & 1.52 & & 0.65 & 6.96 & 2.71 \\
\hline 8 & 29.06 & & 14.32 & 1.64 & 1.53 & 1.48 & & 0.62 & 6.85 & 2.75 \\
\hline 10 & 28.92 & & 14.31 & 1.74 & 1.55 & 1.47 & & 0.57 & 6.65 & 2.79 \\
\hline 12 & 28.35 & & 14.16 & 1.84 & 1.61 & 1.43 & & 0.54 & 6.52 & 2.85 \\
\hline 14 & 28.35 & & 14.12 & 2.17 & 1.68 & 1.38 & & 0.52 & 6.44 & 2.90 \\
\hline 16 & 28.31 & & 14.05 & 2.22 & 1.96 & 1.36 & & 0.52 & 6.43 & 3.58 \\
\hline 18 & 28.05 & & 13.85 & 2.59 & 2.15 & 1.29 & & 0.51 & 5.87 & 2.96 \\
\hline 20 & 28.18 & & 14.06 & 2.78 & 2.75 & 1.25 & & 0.48 & 5.64 & 2.93 \\
\hline S.E. & 0.15 & & 0.12 & 0.15 & 0.09 & 0.07 & & 0.04 & 0.27 & 0.02 \\
\hline C.D. (5\%) & 0.29 & & 0.23 & 0.29 & 0.17 & 0.13 & & 0.07 & 0.53 & 0.04 \\
\hline C.V. (\%) & 4.60 & & 1.86 & 4.29 & 4.05 & 2.87 & & 8.81 & 5.54 & 3.03 \\
\hline
\end{tabular}

Made tea attributes of "China" cultivar, fluctuating. Similar trend was noticed with CI. UPASI-9 presented in Table 4. Thearubigins increased with increasing time of withering period (from 10 to $20 \mathrm{~h}$ ). There was an increasing trend with respect to TR against extended withering period and then declined. Values of TR:TF ratio enhanced from 9.06 as against the extended withering period and the ratio was dropped beyond $16 \mathrm{~h}$ of withering. There was no definite trend in HPS values; it was The values of TLC and caffeine increased with increasing withering period. Concurrent decline in $\mathrm{BI}$ was noticed against the increasing withering period. Water extract showed definite trend against the extended withering wherein WE increased with increasing withering period. Crude fibre content declined from 14.03 to $12.81 \%$ as against prolonged withering period.

Table 4. Made tea quality attributes of "Chinery" clone, UPASI-9

\begin{tabular}{ccccccccccc}
\hline $\begin{array}{c}\text { Sampling } \\
\text { time }(\mathrm{h})\end{array}$ & $\begin{array}{c}\text { TF } \\
(\%)\end{array}$ & $\begin{array}{c}\text { TR } \\
(\%)\end{array}$ & $\begin{array}{c}\text { HPS } \\
(\%)\end{array}$ & TLC & $\begin{array}{c}\text { Caffeine } \\
(\%)\end{array}$ & Cl & BI & TR:TF & $\begin{array}{c}\text { WE (\%) } \\
\text { CFC } \\
(\%)\end{array}$ \\
\hline 10 & 0.87 & 7.88 & 6.65 & 2.85 & 2.40 & 5.97 & 31.79 & 9.06 & 34.88 & 14.03 \\
12 & 0.83 & 8.72 & 6.91 & 2.92 & 2.58 & 5.28 & 30.45 & 10.51 & 36.46 & 13.29 \\
14 & 0.86 & 8.91 & 7.00 & 3.05 & 2.92 & 5.56 & 27.45 & 10.36 & 37.26 & 12.99 \\
16 & 0.91 & 9.23 & 7.45 & 3.41 & 3.53 & 5.91 & 22.74 & 10.14 & 38.32 & 12.93 \\
18 & 0.94 & 9.14 & 6.47 & 3.43 & 3.26 & 7.30 & 22.71 & 9.23 & 39.34 & 12.76 \\
20 & 0.94 & 8.53 & 7.44 & 3.64 & 3.78 & 5.91 & 21.55 & 9.04 & 40.02 & 12.81 \\
S.E. & 0.02 & 0.14 & 0.09 & 0.13 & 0.06 & 0.07 & 0.58 & - & 0.82 & 0.21 \\
C.D. & 0.04 & 0.27 & 0.17 & 0.25 & 0.11 & 0.13 & 1.15 & - & 1.63 & 0.41 \\
C.V. (\%) & 4.18 & 3.52 & 2.15 & 2.06 & 3.74 & 5.44 & 8.47 & - & 10.41 & 3.19 \\
\hline
\end{tabular}


Considering the polyphenol content of the "Assam" seedlings and UPASI-9 varied between 1.54 and $4.89 \%$ as against extended withering period. Degradation of polyphenols was rapid in the case of "Assam" seedlings while UPASI-9 exhibited slow degradation. Alike trend was observed with catechins wherein the variation between "Assam" seedlings and UPASI-9 were very narrow registering the variation ranging from 0.15 to $1.56 \%$. With regard to amino acid content, UPASI-9 was edge over the "Assam" seedling teas. Unlike polyphenols, catechins and amino acids, the values of reducing sugars are fluctuated. Considering the values of total chlorophylls, "Assam" seedlings registered higher values than that of UPASI-9. Contrarily, UPASI-9 possessed marginally higher values of carotenoids than that of "Assam" seedlings. Invariably "Assam" seedlings contained higher amount of lipids than the clonal test material. There was definite pattern in the case of caffeine content with respect to extended withering period.

After drying the fermented "dhool" showed irregular pattern in terms of TF, TR, TLC and WE values both in "Assam" seedlings and UPASI-9. However, TR:TF ratio was increased in UPASI-9 after $12 \mathrm{~h}$ of withering period. Till $18 \mathrm{~h}$ of withering period, "Assam" seedlings exhibited higher values of HPS than that of UPASI-9. Caffeine content of the made tea samples derived from UPASI-9 had marginally higher values than that of "Assam" seedlings and followed the same pattern of caffeine distribution as in the case of extended withering of green leaf, except at 20 hours. Extended withering beyond $16 \mathrm{~h}$ deteriorated the values of colour index while there was no distinct trend in terms of $\mathrm{BI}$ between "Assam" seedlings and UPASI-9 as against extended withering time. Marginal deviation was observed in terms of CFC which is not followed regular pattern.

\section{DISCUSSION}

Even though in the present study, two different study materials i.e., "Assam" seedlings and "Chinery" clone, UPASI-9 were deliberated, in most of the green leaf constituents and made tea attributes were found to be similar trend except certain deviations. It may be noted that "Assam" seedlings represent plant to plant variation in terms of their phenology, biochemical constituents, physiological performance and quality attributes besides the biomass/economic productivity $24,25,26,27,28$. It has been noted that the "Chinery" clone, UPASI-9 exhibited exclusive performance and there was no plant to plant variation ${ }^{29}$

During the physical withering the plucked tea shoots loss its moisture, the cell sap becomes concentrated and the leaf becomes flaccid. During withering process, the biochemical constituents transformed from one form to another i.e., the breakdown of protein, increase in the amount of amino acids. Increase in the amount of reducing sugars ${ }^{30,31}$. Increase in caffeine content and enhanced cell membrane permeability was also reported earlier ${ }^{30}$. On the other hand, decrease in chlorophyll and carotenoids pigments reported by Wickremasinghe ${ }^{32}$. Harder form of withering resulted in loss moisture exorbitantly in turn reduces the brightness and briskness besides biochemical changes at the stage of withering during black tea manufacturing. Results obtained in the present study revealed that the exhibited withering time enhanced certain constituents like total sugars, amino acids and caffeine to an extent. Both the pigments declined when the withering time was extended while there was no significant difference in polyphenols and catechins which substantiated the earlier results of Sanderson and Perera ${ }^{34}$. It has been established that the increase in the contents of sugars, amino acids and caffeine might be due to higher rate of respiration with evolution of carbon dioxide and water molecules, transformation of biochemical constituents.and consequent loss in dry matter content ${ }^{33}$. Decline in the values of pigments may be attributed to raise in temperature ${ }^{5}$. Quality of tea is a polygenic character and influenced by a number if components either directly or indirectly. Belitz et al., ${ }^{35}$ reported that reduction in moisture content during withering can hance the activity of certain hydrolytic enzymes which in turn enhance the values of water extract. Theaflavins is responsible for black tea brightness and briskness. Temperature play an important role in black tea manufacture; during withering process lower temperature can resulted in higher values of brightness and briskness of the tea liquor. Results obtained in the present study established that withering up to $16 \mathrm{~h}$ enhances the quality of processed teas and extended withering deteriorated the liquor characteristics and flavor profile. 


\section{CONCLUSION}

Sixteen hours withering is optimum to achieve good quality processed teas with desirable range of biochemical properties; processing of tea leaves withered within $10 \mathrm{~h}$ resulted in poor biochemical properties. Processing or tea leaves beyond $18 \mathrm{~h}$ also deteriorated the quality attributes of CTC black teas.

\section{ACKNOWLEDGEMENT}

This paper is published with the permission of the Director of the UPASI Tea Research Foundation, Tea Research Institute, Valparai- 642127., South India, India.

\section{Conflicts of Interest}

The authors declare no conflict of interest.

\section{REFERENCES}

1. Barua, D.N. (Ed.) Science and practice in tea culture. Tea Research Association, Calcutta, India., 1989, 509.

2. Jain, J.C. and Takeo, T. The enzymes of tea and their role in tea making, Journal of Food Biochemistry., 1984, 8, 243- 279.

3. Singh, H.P. and Ravindranath. Do polyphenols in phenol rich plant sources affects solubilisation of native PPO.In: Proceedings 59th Annual General Body Meeting of the Society of Biological Chemists, (India), Udaipur., 1990, 123.

4. Omiadze, N.T., Mchedlishvili, N.I., Rodrigez Lopez, J.N., Abutidze, M.O., Sadunishvili, T.A. and Pruidze, N.G. Biochemical processes at the stage of withering during black tea production. Applied Biochemistry and Microbiology., 2014, 50(4), 394-397.

5. Dev Choudhury, M.N. and Bajaj, K.L. Biochemical changes during withering of tea shoots. Two and a Bud., 1980, 27, 13-16.

6. Ullah, M.R. A reappraisal of withering process in black tea manufacture. I. Physical and chemical withers and their effects on tea liquors. Two and A Bud., 1984, 31, 20-24.

7. Saijo, R. Mechanisms of developing black tea aroma with special reference to alcoholic compounds. Japan Agricultural Research Quarterly., 1977, 11, 216-220.

8. Baruah, D., Bhuyan, L.P. and Hazarika, M. Impact of moisture loss and temperature on.biochemical changes during withering stage of black tea processing on four Tocklai released clones. Two and a Bud., 2012, 59(2), 134-142.

9. Dev Choudhury, M.N. and Goswami, M.R. A rapid method for determination of total polyphenolic matters in tea (Camellia sinensis L.). Two and a Bud., 1983, 30, 59-61.

10. Swain, T. and Hillis, W.E. The phenolic constituents of Prunus domesticatus L. The quantitative analysis of phenolic constituents. J. Sci. Food Agri., 1959, 10, 63-68.

11. Moore, S. and Stein, W. H. Methods in Enzymology. (Eds.). S.P. Colowick and N.D. Kaplan. Chapter 3, p. 468, Academic Press, New York., 1948.

12. Wellburn, A.R. The spectral determination of chlorophylls $a$ and $b$ as well as total carotenoids, using various solvents with spectrophotometers of different resolution. J. Plant. Physiol., 1994, 144, 307-313.

13. Hedges, J.E. and Hofreiter, B.T. Determination of reducing sugar method in carbohydrate chemistry. Academic Press, New York., 1962, 1, 388-389.

14. Ravichandran, R. and Parthiban, R. Lipid occurrence, distribution and degradation to flavour volatiles during tea processing. Food Chem., 2000, 68, 7-13.

15. Ronald, S.K. and Ronald, S. Beverages and chocolate. In Pearson's composition and analysis of foods, 9th ed., Longman Scientific and Technical publishers, England., 1991, 356-362.

16. Jibu Thomas. 'Bio-markers' to elucidate the desirable traits for quality and yield in tea (Camellia spp.) germplasm. Ph.D. thesis. Bharathiar University, Coimbatore, India., 2008, 76.

17. Thanaraj, S.N.S. and Seshadri, R. Influence of polyphenol oxidase activity and polyphenol content of tea shoot on quality of black tea. Journal of the Science of Food and Agriculture., 1990, 51, 57-69.

18. Ullah, M.R., Gogoi, N. and Baruah, S. A rapid method for extraction and spectrophotometric determination of caffeine in tea. Two Bud., 1987, 34(1 \& 2), 50-53. 
19. Ramaswamy, S. Improving tea quality in south India. UPASI Tea Scientific Department Bulletin., 1986, 41, 12-24.

20. IS 13862, 1999. Determination of water extract (First revision). Indian Standard Specification for tea (BIS), New Delhi., 1999.

21. IS 13853:Tea-Determination of loss in mass at $1030 \mathrm{C}$, in Indian Standards Specification for Tea, Indian Standard Institution (BIS), New Delhi., 1994.

22. ISO 15598: (E). Determination of crude fibre content in tea, in International Organization for Standardization, Switzerland., 1999.

23. Gomez, K.A. and Gomez, A.A. Statistical Procedures for Agricultural Research. John Wiley and Sons, New York., 1984.

24. Raj Kumar, R., Manivel, L. and Marimuthu, S. Evaluation of clonal characteristics in mature tea. Journal of Plantation Crops., 1993, 21, 241-247.

25. Raj Kumar, R., Venkatesalu, V. and Manivel, L. Clonal variation in carbon dioxide assimilation in tea. Photosynthetica., 1993, 29(4), 600-612.

26. Babu, S. Tea descriptors - Series-I. Planters' Chronicle., 2004. 100(5), 9-12.

27. Babu, S. Tea descriptors: Series-2. Planters 'Chronicle., 2005, 101(1), 12-15.
28. Marimuthu, S. and Raj Kumar, R. Variations in biochemical constituents of south Indian clonal teas., 2001, 312-315. In: Proceedings of 2001 International Conference on O-Cha (Tea) Culture and Science. Session II: Production. Shizuoka, Japan.

29. Venkataramani, K.S. and Sharma, V.S. Notes on the UPASI tea clones approved by Tea Board and released for commercial planting. Planters' Chronicle., 1975, 70, 119-121.

30. Sanderson, G.W. The theory of withering in tea manufacture. Tea Quarterly., 1964, 35, 146-163.

31. Ullah, M.R. and Roy, P.C. Effect of withering on polyphenol oxidase level in the tea leaf. $J$. Sci. Food. Agric., 1982., 33, 492-495.

32. Wickremasinghe, R.L. Tea. Advances in Food Research., 1975, 24, 229-286.

33. Kanthamani, S. Chemistry of tea with reference to quality and classification of tea clones. Planters' Chronicle., 1968, 63, 73-75.

34. Sanderson, G.W. and Perera, B.P.M. Carbohydrates in tea plants.1 .Carbohydrate in tea shoot tips. Tea Quart., 1965, 36, 6-13.

35. Belitz, H.D., Grosch, W. and Schieberle, P. Food chemistry, 4th revised and enlarged edition. Springer, Berlin., 2009, 938-970. 